\title{
Love and Fortune Balance in Marriage ------view of marriage in Pride and Prejudice
}

\author{
Huang Juan \\ Professional Arts Institute of Hubei, Wuhan, Hubei, 430070, China
}

\section{Thesis:}

Marriage is very important to each human being. We should make our eyes to be the brightest ones to find the other halves of ourselves. Love and fortune, the two important matters, are both very important in a happy marriage.

Key words: marriage for so-called love, marriage of convenience, for money, ideal, happy marriage, happy ending “comedy", focus much on love matter

\section{Background of the great female writer Jane Austen.}

Ignored the eighteenth century or viewed it as a period of unenlightenment. According to recent studies, the changing role and increasing importance of women was one of that period's vital events. Without thinking themselves as feminists in the current scene or developing a political program, indeed, while often disguising their purposes or apologizing for their behavior, English women of the eighteenth century made concern about the "woman question". An active issue, especially with respect to a woman's right to choose her husband and their right to educated that is her right to knowledge. Jane Austen was among those authors.

Little is directly known of Jane Austen's acquaintance with the developing female consciousness in the eighteenth century. That she examines the "drama of women" in her novels is a judgment based on the likelihood that she was sensitive to her social and literary environment, on the similarity between her views and those of "feminist" writers of the 1790s, and, above all, on the evidence of the novels themselves.

Jane Austen was born 16 December 1775, the seventh of eight children in 
pleasant country patronage in the small Hampshire village of Steventon. She was brought up in an intelligent but restricted environment. Her father was a rector and a fine scholar with a good library. After a few years' schooling, she and her sister Cassandra continued their education at home, mainly through widely reading the books and materials available, and through frequent male companionship and those interesting discussions of their brothers and those young men their father had taken at their home as students. Jane acquired a thorough knowledge of English eighteen - century literature, including the moral philosophy of Dr. Johnson, the poetry of W. Cowper as well as the novels by Richardson and Henry Fielding. In addition, she was much influenced by Fanny Burney, authoress of quite a few novels.

Jane Austen led a quite, retired and uneventful life. She seldom left her home place except for some short visit to such places like Bath, Sputhampton and Chawton. She never married. In 1817, this bright, attractive little woman died, quietly as she had lived, at Winchester and was buried in the cathedral. She started writing very early. Though what she wrote was only intended for the years of her family, for their amusement in the sitting-room in the quiet evening, her genius as an artist was recognized from the very beginning. The whole family encouraged her and her father took responsibility of arranging the publication of her novels. In her brief lifetime she wrote six complete novels: Sence and Sensibility, Northanger Abby, Pride and Prejudice, Mansfield Park, Emma, and Persuasion, among which, Pride and Prejudice is the most well known and popular one. Unfortunately, the novels of Jane Austen are now ranked among the truly great British novelists. Almost six of her novels deal with the business of getting married. So what on earth does the author convey in them? I would like to focus on the representative one------ Pride and Prejudice.

\section{Introduction of the novel Pride and Prejudice.}

An early version of Pride and Prejudice was written in 1796-1797 under the title First Impression, but it was heavily revised before publication in 1813 .

Mr. and Mrs. Bennet and their five daughters live in the village of Longbourn in Hertfordshire. When the wealthy Charles Bingley lease the house of Netherfield near Longbourn and comes to stay there accompanied by his friend Fitzwilliam Darcy, Mrs. Bennet has high hopes that some of her daughters will be married. Mr. Bingley and Jane, the Bennets' sensible eldest daughter, are attracted to each other when they meet at the Meryton assembly ball, but Darcy's cold and proud behavior offends Jane's younger sister Elizabeth, a witty and intelligent young woman who is her father's favorite. Elizabeth's prejudice against Mr. Darcy is confirmed when Mr. Wickham, an attractive young officer, claims that Darcy threat him out of an inheritance left by his godfather, Darcy's father. Darcy and the Bingly sisters, disgusted by the vulgarity of Mrs. Bennet, persuade Bingley to abandon his interest in Jane and return to London.

Mr. Collins, who is a foolish clergyman, will inherit the Bennet property for 
entail, arrives at Longbourn and proposes to Elizabeth, but she rejects him with her father's approval. Mr. Collins, who is a favorite of Mr. Darcy's aunt, lady Catherine de Bourgh, next proposes to Elizabeth's friend Charlotte Lucas, who accepts him. Visiting Charlotte and her husband on Lady Catherine's estate, Elizabeth meets Darcy again and is surprised when he proposes to her. She refuses him, only to be shocked and astonished when Darcy writes a letter which convinces her that Wickham is a deceitful adventurer who tried to elope with Darcy's sister.

Elizabeth makes a trip to Derbyshire with her worthy uncle and aunt from London, Mr. and Mrs. Gardiner, and while they are in Derbyshire they decide to visit Darcy's country estate, Pemberley, believing that he is absent. Darcy appears unexpected on the scene, insists on introducing Elizabeth to his younger sister, and is in every way a changed man, perfectly agreeable. Elizabeth learns that her wayward sister Lydia has eloped with Wickham, and without her knowledge Darcy tracks down the couple and sees that they are properly established. Bingley and Jane renew their love, and after Elizabeth learns of Darcy's generosity she realized her love for him and they are reconciled, in spite of the opposition of the proud Lady Catherine. At the end of the novel Elizabeth and Darcy are settled in Pemberley, where they are visited regular by Mr. and Mrs. Gardiner and Elizabeth's father.

Pride and Prejudice has always been the most popular of Jane Austen's novels because it satisfies our natural longing for the probable and the possible. The social world of Darcy and Elizabeth is scrupulously described, but within these limitations the hero and heroine are allowed to achieve freedom and self-expression. Like all truly classical artists, Jane Austen welcomed the opportunity to demonstrate her freedom within our sense of social rightness and our sense of personal style. "Pride and Prejudice has often been compared to the music of Mozart, because it gives us a sense of liberation, while obeying the strictest laws of form and structure." (H. Abigail, Bok 335)

This novel exhibits lots of social phenomenon in the interval of 18th and 19th century. This novel wrote about, among the upper classes in early 19th century England, a kind of "trade" - what we could today call business and commerce was looked upon as being beneath the dignity of cultivated people. To spend one's time in avid pursuit of money - profit - was, therefore, vulgar. Business was not the traditional occupation of the great families of England who derived their incomes from the possession of land, The Bingley girls ( and Sir William and Lady Lucas), who were not the heirs of old families of the landed gentry, wished, therefore, to play down the origin of their new wealth and social status. One of the lessons of the story is that snobbery is not an indication of good manners and that occupation is not an indication of moral worth. This is one of the cultures of the old England, and it will influence the marriage affair. There were lots of such kinds of reveals. But what we really have to pay attention to is the marriage affairs in the novel.

To reunite sex, love and marriage, separated within the individual psyche and in relationships between men and women by society's low evaluation of wedlock, is one of Austen's major purposes in Pride and Prejudice (W. Smith, Le Roy 96). 
In the dictionary the term marriage is defined as: the instruction under which a man and a woman become legally united on a permanent basis; the act of entering into this institution; the wedding ceremony; the entering into the married state as a Christian sacrament; an intimate linking together, (cards) the declaration of king and queen of the same suit esp. in pinochle or bezique. So what about Jane Austen's view of marriage reveals in her work? I will analyze this through the three kinds of marriage style in this famous novel - Pride and Prejudice.

\section{Three kinds of marriage style.}

First we come to the abnormal, foolish marriage for so - called love, the marriage of Lydia Bennet and George Wickham, Mrs. Bennet and Mr. Bennet.

George Wickham is a key character we must notice. He attached to the evil deeds of elopement twice in the novel. His appearance was greatly in his favor. Brought up and educated by Darcy's father. Wickham has acquired the taste for a life of leisure but none of the self-discipline and moral integrity that characterize Darcy. As Lydia's affection was completely undiscriminating, held by no moral check, so is Wickham's pursuit of a woman with a fortune. He easily shifts his attention from Elizabeth to Miss King, and is persuaded to marry the girl he ran off only by the promise of money and a commission in the Army (which Darcy obtains for the man who tried to destroy his reputation). Like Lydia he has no morality - hence to prudence. He soon tires of his wife. The nervous fright in his manner when Elizabeth confronts him with her knowledge of the truth symbolizes the man's general ineffectuality. Then the final mate of Wickham, Lydia is the youngest, the tallest, the boldest, the most vulgar, and the most imprudent of the sisters. There are indications that her superficial and flirtation character is not unlike what her mother's was at her age. Completely non-moral, she has not sense of remorse or shame; on the contrary, she triumphs at her living with Wickham before marriage. Her marriage, based on physical attraction merely, is doomed to failure. Her elopement, however, serves a useful purpose for it give Darcy the occasion to come gallantly to the aid of the Bennet family and show how he can swallow his pride and deal with the hated Wickham, all for the love of Elizabeth. "Lydia was a stout, well-grown girl of fifteen, with a fine complexion and good-humored countenance; a favorite with her mother, whose affection had brought her into the public at an early age. She had high animal spirits, and sort of natural self-confidence, which the attention of the officers, to whom her uncle's good dinners and her own easy manners recommended her, had increased into assurance." (Wu, Jingrong 47)

The two are described as brought together because their passions were stronger than their virtue. So this is the tendency to marry for beauty, attraction and passion regardless of economic conditions or personal merits. This is also generally known as "love at first sight". Such typical examples in The novel besides Wickham and Lydia, there is also Mr. Bennet and Mrs. 
Bennet who has a beautiful face but an empty head. "The author states that in Bennet contrast to the wit, humor, and complexity of mind of her husband, Mrs.

was a woman of 'mean understanding, little information, and uncertain temper."” (J. Fitzpatrick, William 23)

There is a typical plot:

"My dear Mr. Bennet," said his lady to him one day, "have you heard that Netherfield Park is let at last?"

Mr. Bennet replied that he had not .

"But it is," returned she,"for Mrs. Long has just been here, and she told about it."

Mr. Bennet made no answer.

"Do not you want to know who has taken it?" cried his wife impatiently.

"You want to tell me, and I have no objection to hearing it."

This was invitation enough.

(Wu Jingrong 1)

From this dialogue we have no difficult to view the obviously different character of the couple. They are couple, but they talk in this way. The terrible aftermath of such love marry is only too obvious in the marriages of the two generation of the Bennet.

Although Jane Austen lived in an age in which marriage of convenience were frequent and matrimony was often almost the only means of support for a woman, she insisted that love was necessary for a happy marriage. Comprehended in her idea of love were esteem, moral approval; and the attraction that is merely stimulated by beauty rather than based on respect for a sound character. Jane Austen disapproves of those who marry for money alone. The marriage of Charlotte Lucas in Pride and Prejudice becomes a test case. It is a grim picture, but perhaps statistically not a wildly inaccurate one, for such married couples. Elizabeth, however, though her family circumstances are similar to Chalotte's, is true to her principles and wins her place as heroine and her happy marriage by rejecting not only Mr. Collins and his parsonage but Mr. Darcy and his 10,000 pound a year until she is sure she can love him, too. The issue of the delicate balance between love and worldly wisdom is explored in some detail in this novel in particular in the context ode Mrs. Bennet's desperate mission to get her five daughters married and off her hands. Elizabeth asks, "What is the difference in matrimonial affairs, between the mercenary and the prudent motive? Where does discretion end, and avarice vegin?" (Wu 153). And though we are convinced that by the time she accepts Darcy she does love him, she herself jokingly suggests that her love began when she first saw "his beautiful grounds at Pemberley" (Wu 373)

While the young people in the novels are finding their mates, by legitimate and illegitimate means, they are surrounded by an older generation that is already married, like the parents of Cathrine, Elizabeth, and Fanny. Marriage and its deprivation, then, are in one way or another context for the courtship of the major characters. But how marriage is may be presented as the consummation most 
devoutly to be wished for the young people, the examples of couples around them are often far from encouraging. Although Jane Austen writes romantic comedies, she is also a sharp satirist, and the sharpness predominates in her depiction of the Palmers, the Dashwoods, the Middletons, the Eltons, and Bennets. "My child," says Mr. Bennet to his favorite daughter, with a rare touch of feeling, "let me not have the grief of seeing you unable to respect your partner in life" (Wu 376). The Bennets girls might well wonder that their mother should be so eager to push them into the married state.

Although some have thought that Jane Austen "had more acuteness, Penetration \& Taste, than Love" (Letters, November 18,1814), most readers who have come to know her novels well have found that she memorably and successfully dramatizes the perennially interesting topic of the proper choice of a mate.

There is some extra things. From consequence of the elope affair between Wickham and Lydia we might wonder at the Bennets's conceiving to sensible alternative for Lydia but to marry the man with whom she has ran away. But to Jane Austen's readers, this was the only respectable out come. A worthwhile gentleman of the middle class would not consider marrying a girl who had run off with another man. The only way was she can in some measure be restored to good society is by marrying the man who seduced her. Otherwise, she will end up an old maid, or marry someone beneath her. It's also a kind of unfair between male and female.

\section{Marriage of convenience, money.}

The second kind of marriage was merely for fortune, money and social rank. This is to be found in Miss Bingley's pursuit of Darcy, Lady de Bourgh's intention to arrange a marriage between her daughter and Darcy, and in Charlotte Lucas's marriage to William Collins. Marriage of convenience is the kind of marriage to William Collins. Marriage of convenience is the kind of marriage made not for love, but for the personal benefit of one or both partners.

Austen shows that a due attention to income is necessary in this kind of marriage was merely for fortune, money and social rank. This is to be found in Miss Bingley's pursuit of Darcy, Lady de a couple considering matrimony, but she disproves of those who marry to money alone. The marriage Charlotte Lucas becomes a test case. Reverend William Collins, was not a sensible man, and the deficiency of nature had been but little assisted by education or society, the greatest part of his life having been spent under the guidance of an illiterate and miserly father; and though he belonged to one of the universities she had merely kept the necessary terms, without forming at it any useful acquaintance. The subjection in which his father had brought him up had given him originally great humility of manner, but it was now a good deal counteracted by the self-conceit of a weak head, living in retirement, and the consequential feelings of early and unexpected prosperity. A fortunate chance had recommended him to Lady Catherine de Bourgh when the living of Hunsford was vacant; and the respect 
which he left for her high rank, and his veneration for her as his patroness, mingling with a very good opinion of himself, of his authority as a clergyman, and his right as a rector, made him altogether a mixture of pride and obsequiousness, self-importance, and humility.

Collins is the correlative to, and justification of the snobbishness of the upper classes. Indeed, he partakes of this snobbishness and social pride in his very servility. His complete lack of self-consciousness permits the ironies that make him perhaps the most comic figure in the book. His moral confusion and pretentiousness are reflected in his over elaborate speech and style of writing. As the first of Elizabeth's suitors, he represents the kind of marital compromise that trades all natural feeling for economic security. His rude and pompous proposal is strangely like Darcy's in his firm conviction that she has no choice but to accept him. But despite his comic absurdity, the dullness and self-importance of this unimportant man, his moral density (his Christianity seems a mere masquerade recall his advice about Lydia) has a sinister and uncomic cast. The smell of evil is about him, like Wickham. Collins has great importance in the plot. Twice he brings Elizabeth and Darcy together, first, at Hunsford, second by telling Lady Catherine about Jane's forthcoming marriage to his friend, thereby intimating that her nephew might be interested in Elizabeth.

Charlotte Lucas is plain, and twenty-seven, and can look forward to a life as a governess or to living, not very comfortably, dependent on her parents. Like Caroline Bingley, Charlotte serves as foil for Elizabeth. Whereas Caroline's desperation leads her to a vulgar pursuit of Darcy. Charlotte's poor prospects for a life of material comfort lead her to pounce on Mr. Collins as soon as Elizabeth casts him off. She appears to do this with fully awareness of his deficiencies. This proves she has then intelligence to be Elizabeth's friend. Her deficiency is moral one, as Elizabeth explains in chapter 24. The calculating way she chooses a mate balances Lydia's impulsive, animal motive. As Elizabeth instructs us, a prudent choice in marriage balances natural attraction and rational reflection. Charlotte loses her balance. In fact Charlotte is wise enough to point out that Bingley likes Jane undoubtedly; but he may never do more than like her, if she does not help him on. What she said is the most essential problem between Mr. Bingley and Jane. Although more perceptive than Mrs. Bennet, her view of marriage is rather line hers. Charlotte takes Collins "solely from the pure and disinterested desire for an establishment". Collins's decision is equally untouched by affection; rather, it is inspired by Lady Catherine's promptings. We may notice how quickly he moves from Jane to Chalotte - making two proposals in three days. Chalotte explains her decision to her friend:

"... when you have time to think it all over, I hope you will be

satisfied with what I have done. I am not romantic. I never was. I ask

only a comfortable home; and considering Mr. Colins's character, connections and situation in life, I am convinced that my chance of happiness within is as fair, as most people can boast on entering the marriage state."

(Wu Jingrong 137) 
In fact she has no more choice; she is twenty-seven years old already. The society, her family and herself do not allow her to choose any longer. She couldn't just wait and select to be an old maid at last. The real fact is ruthless. The snobbery and vanity of the rich and the practicality of the poor gentry's women are fully accounted for. But Charlotte is not severely punished and managed to be reasonably happy in her home at Hunsford, particularly when her husband is not at hand. Poor woman.

The arguments that Austen's heroines are engaged in a search for a new and better father, that their happiness depends on their gaining male approval and protection, and that the "cover story" dramatics the necessity of female submission are equally suspect. It refers to the parentage cause for the female in getting good marriage. At this point I want to introduce one extra factor which slightly complicates this straight forward opposition between moral and economic criteria. When Jane Austen was writing (and until 1870) married women legally owned nothing: all their property belonged to their husbands. Yet the only way to financial security for many women of the time was through marriage to a rich man. So there is an added irony in these families seeing the eligible young man as the "rightful property" of one of their daughters. If anyone was to be in possession in financial terms, it would be the young man himself and the daughter's parents would effectively sell their daughter, like a piece of property, in exchange for financial relief. In the context of this immediate opposition, the word in the passage, it suggests that for these families marriage is about possession, not only of a fortune but also of a person - indeed the two seem to be completely identified. Again, the reader (and particularly a modern reader) might want to argue that marriage should be about partnership, a moral contract between individual, rather than a financial takeover of ownership and these two opposing ideas of marriage reinforce the basic opposition between money and love. I'm going to look at the novel's famous opening lines. The immediate focus here is on the link between money and marriage:

It is a truth universally acknowledged, that a single man in possession

of a good fortune, must be in want of a wife. However little known the feeling

or views of such a man maybe on his first entering a neighborhood, this

truth is so well fixed in the minds of the surrounding families, that he is

considered as the right property of someone or other of their daughters.

(Wu Jingrong 1)

Our immediate assumption is that the point of view in the opening sentences is that of the narrator, because of the authority with which this "truth" seems to be presented, but closer analysis suggests this is perhaps not the case. That's the marriage of convenience. Though it's not a ideal one, it's a happy one. There is the foundation of fortune for living to make up the lack of love.

\section{Ideal marriage style.}

Now comes the ideal marriage, which is a love match with consideration of the lover's personal merits and economic conditions. Such as perfect happiness is to 
be found in the marriage of Fitzwilliam Darcy and Elizabeth Bennet and that of Charles Bingley and Jane Bennet, although the satisfaction of both the personal and economic conditions like this is really a bit too idealistic.

"I must confess that I think her as delightful a creature as ever appeared in print, and how I shall be able to tolerate those who do not like her at least, I don't know (from Jane Austen's Letters)." Although not so beautiful as her sister Jane, Elizabeth is quite attractive. Her striking eyes and flashing wit denote a personality every bit the match for Darcy's. She has inherited her father's sense of humor and irony, but without his cynicism. Her ability to see humor in Darcy's slighting her, her disregard for decorum in tramping off through the mud to visit her sister, her critical and witty conversation, reveal a vigorous and intelligent young woman superior to, and without the pretense of, the society around her. Much of the story is seen through her searching intelligence. She is constantly reacting to the self-revelations of others, and in so doing reveals the positive standard of morals and good sense. Her judgment of Mr. Collins and Charlotte, her embarrassment at her family's crudities, her appreciation of Pemberley - her high moral standards, good manners, and taste - distinguish her from Longbourn. This makes Darcy's victory over his pride easier - social more rational - than it might otherwise have been. We must not forget that Elizabeth is "not yet one and twenty". This somewhat accounts for her lively, "impertinent" spirit, for her pride in her own and perception, and for her susceptibility to Wickham's charms. She has not yet had much experience in life and, in a way; the novel is the story of completion of her education. She has more to learn than she thinks she has, and the reader delights in the irony that at the moments when she is triumphing in her wit - during the several dialogues with Darcy in the first half of the book - she is most deceived about the effects of her sharp remarks.

Her prejudice has two aspects: it is against Darcy because of his insult to her and his pride; it is for Wickham because of his attractiveness and attentions to her. Events force her to turn her critical scrutiny inward, and she reveals her honesty and courage and flexibility by forthrightly facing the truth about herself and others. This constantly busy intelligence is Elizabeth's salient trait. It becomes a virtue that transcends class lines. It is Elizabeth's consciousness of her own superiority that permits her to stand up proudly to Lady Catherine and to reject Darcy's insulting proposal. Yet, with all her intellectual and moral superiority and her proud independence and unconventionality, she is not marked with the egotism we see in most of the other characters. Her attempt to step into the gap caused by her father's abdication of his responsibility, again reveal a maturity of Darcy. In Elizabeth we see action guided (at last) by reason, informed by self-knowledge. She is model of prudent behavior, and her marriage is the measure of the others in the book.

"Mr. Darcy soon drew the attention of the room by his fine, tall person, handsome features, noble men; and the report that was in general circulation within five minutes after his entrance, of his having ten thousand a year. Till his manners gave a disgust which turned the tide of his popularity; for he was discovered to be proud; to be above being pleases." (Wu Jingrong 7)

Darcy enters the plot almost accidentally, though his friendship with Bingley. 
Everyone (including Darcy) is busy with the romance of Bingley and Jane, when all the time below the surface the real drama is taking place in the half-suppressed and halting growth of Darcy's and Elizabeth's love for each other persons in the novel. Darcy's character is a challenge to the perceptiveness of all the other persons in the novel. The many different interpretations of his personality establish him as one of those "intricate" characters Elizabeth says are most amusing. Along with Elizabeth and Mr. Bennet, he is capable of thought and self-scrutiny. His true complexity and moral worth is revealed gradually and is a correlative to Elizabeth's own essay in self-discovery. Almost alone of all the character is he variously interpreted. The reader is not given a complete picture directly, but rather Darcy is presented as seen by Elizabeth, Bingley, Georgiana, Wickham, Caroline, Mrs. Bennet, Mrs. Reynolds, Meryton, Lambton.

As a member of the great landed gentry and of noble descent on his mother's (Lady Anne Fitzawilliam) side (and having been spoiled as child), Darcy embodies the pride of his superior social status - thus the objection to Elizabeth's low connections. But although events force Darcy to modify his snobbish identification of social desirability and social status, his pride is revealed to have a stronger root in his consciousness of being the possessor of superior intelligence and will. This makes him contemptuous of the trivial socializing that amuses his friends, and disdainful of Caroline Bingley's vulgar pursuit. He has the virtues of his social position; he is liberal and honorable - and in the end, humbles him and makes him worthy of love.

The two met at party, they have lots of commonplace. Elizabeth superiority to her sister in insight and wit is paralleled in Darcy's superiority to his friend. Initially, Elizabeth and Darcy square off as types of the female struggling for freedom and the conventional male oppressor. Each is deeply influenced by the concept of roles, which leads one individual to judge another primarily as society thinks that person ought to be. Its companion is the concept of stereotypes, which, by stressing the differences between masculine and feminine identity, restricts one's hope of finding in the opposite sex those qualities that would minister to one's own human needs. Roles and stereotypes are learned. They are internalized and become part of 'the fabric of one's psyche and personal relationships'. Darcy appears at Meryton as a refined product of the patriarchal order: handsome, self-assured, cultivated and apparently confident of his superiority. Elizabeth is annoyed by the scrutiny of 'so great a man', who she assumes dislikes her. She accuses him of being proud, in the sense of possessing and overweening an overweening self-ragar and love of rule, in the manner of Lay Catherine de Bourgh. As a reflection of the 'rituals of patriarchy', she assumes that Darcy's attitudes can be predicted by Lady Catherine's.

Patriarchal patterns of thought do control Darcy's performance until well after his proposal at Hunsford. Like a patriarchal father who seeks to prevent a child's imprudent marriage, he interferes with the friendship of Jane Bennet and Bingley. When he finds himself strongly attracted to Elizabeth, he resolves, because of 'the inferiority of her connections', 'to be particularly careful that no sigh of admiration should now escape him, nothing that could elevate her with the hope of influencing his felicity'. He informs her, finally, that because of his 
irrepressible feelings he has decided to overlook 'his sense of her inferiority - of its being degradation - of the family obstacles which judgment had always opposed to inclination' - and to make her an offer of marriage. Darcy's proposal is as Collins's: he makes the same assumption that he will not be refused; he is as tactless, or more so, in telling her that he likes her against his will, his reason and even his character; and he receives her refusal with greater resentment. Elizabeth informs Darcy that no proposal from him would have tempted her. Despite an initial sense of gratification at having 'inspired unconsciously so strong an affection', anger at Darcy's 'pride, his abominable pride', soon rule her thoughts.

Against the background of the marriage market Elizabeth Bennet acts the "drama of woman", the "conflict between the fundamental aspirations of every subject (ego) - who always regards the self as the essential - and the compulsions of a situation in which she is the inessential". She is expected to subordinate her will needs and interests to those of the superior male sex, to accept a life of passivity and dependency, and to welcome an unloving and unequal marriage. But Elizabeth rejects both the feminine stereotype and the feminine role. She can think for herself and intends to make her own decisions. She insists that she be treated and judged as an individual. Elizabeth describes the proposal as "almost incredible" but her declaration of independence - "You could not have made me the offer of your hand in any possible way that would have tempted me to accept it" (Wu 208-209) - is an unthinkable response by a young woman in her circumstances. Darcy's astonishment and his mortification are obvious. Hunsford, however, marks the turning point in their relationship. At Hunsford their expectation are shaped by their assumptions about masculine and feminine behavior. Both disdain the marriage market and insist on something better than practicality as a basis for marriage, but each mistakes the other with the general view. At Hunsford both experience the frustration and pain of being judged by a stereotype rather than as an individual and both are mortified by the result. Darcy is startled by Elizabeth's stern reproof of his conduct and she learns from his subsequent letter that her behavior has been grounded in a prejudice that distorts reason. They discover how stereotyping has inhibited their ability to achieve their personal goals.

Both Darcy and Elizabeth demand that they be judged as individuals, both discover how difficult it is to shake off conventional modes of thought in judging others, and both come to realize that correct judgment depends upon a knowledge of both oneself and the other, an attitude inherently at odds with entrenched sexual assumptions. But instead of blaming the other, they begin the difficult task of removing the imprint of sexual stereotyping on their own behavior. On their success rests their chance of discovering their individual human potential and of arriving at an intimate personal relationship. Overcoming the obstacle of their pride and prejudice, they combined to be the perfect couple in the novel at last. They marry for both love and fortune.

Bingley and Jane's marriage is another kind of ideal marriage, which is different from Darcy and Elizabeth's. The love between them is focus much on their mutual nice appearance. It is the appearance that fascinated each other. Their marriage is also the ideal marriage, because their marriage do including the 
two pivotal elements_- "love" and fortune.

\section{Ending}

As this analysis of the elements combined in Elizabeth and Darcy's marriage suggests, it has an important symbolic role in the novel. This is true of the marriages at the end of all Jane Austen's novels. They provide a satisfactory romantic ending to the events in the story, but also a significant culmination of the moral concern of the plot. Jane Austen's novels are romantic comedies. That is, they are love stories with happy ending. "Comedy" here is used not so much to suggest something which makes us laugh, though Jane Austen's novels often do that as well, but as the opposite of "tragedy". In other words, it describes a positive, celebratory view of life, one that presents happiness and ideals as possibilities. Jane Austen's novels are often compared with Shakespeare's comedies, and if you are familiar with any of these you will know that the plays end a very similar way, with marriage which symbolizes reconciliation and harmony.

The dominant emphases are a conservative view - Austen is primarily a moral writer, she accept the structure and values of her society, and she is indebted to the eighteenth century for her beliefs - and a radical view - her fiction exhibits a division within her mind and personality and conflict with her society. The conservative view has the longer and fuller history. The radical view dates from D.H. Harding's essay, "Regulated Hatred: An Aspect of the Work of Jane Austen", in 1940, and from Marvin Mudrick's study, Jane Austen: Irony as Defense and Discovery, in 1952. Harding argues that Austen is a "literary classic of the society which attitudes like hers, held wide enough, would undermine", and that her object in writing is the "desperate one of merely finding some mode of existence for her critical attitudes". Mudrick states that Austen's irony provides a means of avoiding "a full commitment" to the "deeply conformist and self-complacent" in which, willingly or not, she was trapped. Distance - to protect her reserve, to "put off self-commitment and fleeing" - was her first condition for writing.

Austen lived in a hierarchical society organized on patriarchal principles. As defined by a defender, a patriarchy "associates authority and leadership primarily with males ... [who] fill the vast majority of authority and leadership positions". As defined by an opponent, it is a "system in which men - by force, direct pressure, or though ritual, tradition, law, and language, customs, etiquette, education, and the division of labor, determine what part women shall or shall not play, and in which the female is everywhere subsumed under the male". Both proponents and assailants regard patriarchy as an ancient, universal and dominantly masculine society.

From the three kinds of marriage styles, we can see that Jane Austen's view of marriage through those is love and fortune balance in a happy marriage. Jane Austen's works included almost all about the common people's daily life, and about the marriage and love triviality. Thus many Chinese readers may doubt her high fame in the western world. But the depth of penetration and the artistic and 
ideological strength oaf novel really do not depend on the importance of its subject matter. In fact, Austen's works have been compared to olives: the more you chew them, the better the taste; not only because her language was full of splendor and her writing made creative contribution to the development of the art of novel, but because her light and lively narration was neither superficial nor transparent as it seemed. As Mrs. Smith once put, women writers have an inclination to reshape the existing value and order and change people's views on matters of "importance" and "triviality". May Austen's novels can teach us to alter our view and dimension, to observe the significance through the "triviality".

\section{Work Cited}

[1] Fadiman, Clifton, The New Lifetime Reading Plan. Hainan Press, 2002: 196-203.

[2] H. Abigail, Bok, The Jane Austen Companion. New York: Macmillan Publishing Company, 1986.

[3] Hou, Ruide, A Comprehensive History of English Literature. Shanghai Foreign Language Education Press, 1997.

[4] J. Fitzpatrick, William. Jane Austen's Pride an Prejudice. Foreign Language Teaching and Searching Press, Simon \& Schuster International Press Company, 1996.

[5] Jones, Vivien, How to Study a Jane Austen Novel. Macmillan, 1987

[6] M. Gilbert, Sandra, The Norton Anthology of Literature by Women. W. W. Norton \& Company .New York. London, Second Edition

[7] Oxford Advanced Learner's English-Chinese Dictionary. The Commercial Press, Oxford University Press.

[8] Spencer, Jane, The Rise of the Women Novelist. From Aphra Behn to Jane Austen, Great Britain: Basil Blackwell, 1986.

[9] Watson, Owen, Longman Modern English Dictionary. Great Britain: Richard Clay (The Chaucer Press), 1976.

[10] W. Smith, Le Roy, Jane Austen and the Drama of Woman. Macmillan Education, 1983.

[11] Zhang, Boxiang, and MaJianjun, A Course Book of English Literature 11. [1] Wuhan University Press.

[12] Zhang Zhiqing, The Historical Theory of European and American Literature. Beijing: The Science Press, 2002. 